\title{
Indian scenario of IgA nephropathy: a systematic review and meta-analysis
}

\author{
Anju Khairwa
}

Departments of Pathology, ESIC Model Hospital, Gurugram, India.

\begin{abstract}
Background: $\operatorname{IgA}$ nephropathy $(\operatorname{IgAN})$ is most common primary glomerulopathy. There are variations in prevalence of IgAN and its clinical features in different studies from India.

Aim: To summarize overall scenario of IgAN in India.

Methods: In this systematic review, studies related to IgAN and related renal disease were included. Data searched were PubMed, EMBASE, Google scholar, and Cochrane Database from inception to 31st January 2019

Results: Total 49 studies $(\mathrm{N}=2480)$ were included: 21 studies $(\mathrm{N}=2309)$ of primary $\operatorname{IgAN} ; 19$ studies $(\mathrm{N}=21)$ of Secondary IgAN; four studies $(\mathrm{N}=133)$ of $\operatorname{IgA}$ vasculitis nephropathy $(\operatorname{Ig} A V N)$; and five studies $(\mathrm{N}=17)$ of IgA dominant nephropathy (IgADN). Prevalence of IgAN was $16.5 \%$ in India. Age of affected persons was ranging from $27.2 \pm 16.7$ to $48.6 \pm 21.3$ years . Male female ratio was 1.8:1. Clinical features of Primary IgAN, IgAVN, IgADN \& Secondary IgAN were microscopic hematuria $(49.6 \%, 44.4 \%, 15.6 \% \& 59.5 \%)$, macroscopic hematuria $(5.1 \%, 0.4 \%, 40.9 \%, \& 35.7 \%)$, Subnephrotic proteinuria $(42.1 \%, 29.4 \%, 23.2 \%, \& 52.3 \%)$, nephrotic proteinuria $(16.0 \%, 4.4 \%, 76.8 \%, \& 47.6 \%)$, and hypertension $(25.8 \%, 18.3 \%$, $35.5 \%, \& 47.6 \%)$. The 24 hours proteinuria was ranging from $2.6 \pm 1.5$ to $4.7 \pm 2.3 \mathrm{gm} /$ day and serum creatinine $(\mathrm{mg} / \mathrm{dl})$ was ranging from $0.9 \pm 0$ to $3.5 \pm 3.9 \mathrm{mg} / \mathrm{dl}$. Histolomorphologically, all type of IgAN showed mesangial hypercellularity and Immunofluorescence revealed IgA deposition..
\end{abstract}

Conclusion: The overall prevalence of primary IgAN in India was $16.5 \%$. The subnephrotic proteinuria and microscopic hematuria were common clinical features.

Keywords: IgA Nephropathy; histomorphology; prevalence; India.

DOI: https://dx.doi.org/10.4314/ahs.v21i1.21

Cite as: Khainwa A. Indian scenario of Ig A nephropathy: a systematic review and meta-analysis. Afri Health Sci. 2021;21(1):15965. bttps:// dx.doi.org/10.4314/abs.v21i1.21

\section{Introduction}

$\operatorname{Ig}$ A nephropathy ( $\operatorname{IgAN}$ ) was first demonstrated by Berger in $1768 .{ }^{1}$ It is characterized by persistent microscopic hematuria, sub-nephrotic proteinuria, episodic gross hematuria, normal to severe impairment of renal function and hypertension. ${ }^{1,2}$

Histomorphology varies from normal to chronic glomerulonephritis on renal biopsy of these patients. The most common histomorphology is focal glomerulonephritis. ${ }^{1,2}$ On immunofluorescence microscopy (IF), all cases had mesangial deposition of IgA dominantly and less commonly weak staining for IgG and C3. Theelectron microscopy (EM) had presence of mesangial immune complex deposits. ${ }^{1,2} \operatorname{IgA}$ nephropathy is most common primary glomerulonephritis world-wide.,34 IgA nephropathy mostly diagnosed in certain Asian

\section{Corresponding author:}

Anju Khairwa,

F-92, Ansari Nagar West, New Delhi-110029, India

Phone- +919810436138,

Email-anjukhairwa@gmail.com countries, e.g. Japan, Mainland China, and Singapore. ${ }^{5,6}$ The incidence of IgA nephropathy ranges from $4.0 \%$ to $35.5 \%$ in the world. ${ }^{7}$ IgA nephropathy occurs in all age groups from children to elderly peoples, but it mostly affected age group is 10 to 40 years.. ${ }^{8}$ Clinically features of patients with IgA nephropathy include microscopic hematuria or gross hematuria after one to two days or at a time of fever or upper respiratory tract infection (sore throat), but occasionally it may be associated with gastroenteritis, pneumonia, or urinary tract infection. ${ }^{9}$ It may remain asymptomatic and diagnosed incidentally or during routine screening of urine. ${ }^{9}$ The incidence and prevalence of $\operatorname{IgA}$ nephropathy is varied in different studies from India. ${ }^{7}$ Aim of index study was to evaluate the scenario of $\operatorname{IgA}$ nephropathy in India.

\section{Methods}

We performed a systematic review and meta-analysis to assess the overall scenario of IgAN in India. We included studies of $\operatorname{IgA}$ nephropathy and $\operatorname{IgA}$ related renal diseases reported from India. Type of studies included were observational studies. We excluded randomized controlled trials and studies from outside of India. Stud-

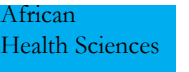

(C) 2021 Khairwa A. Licensee African Health Sciences. This is an Open Access article distributed under the terms of the Creative commons Attribution License (https://creativecommons.org/licenses/BY/4.0), which permits unrestricted use, distribution, and reproduction in any medium, provided the original work is properly cited.

African Health Sciences, Vol 21 Issue 1, March, 2021 
ies including both children and adults were eligible for inclusion in the review. Renal biopsy was considered as reference standard. We searched PubMed (inception to $31^{\text {st }}$ January 2019), EMBASE (inception to $31^{\text {st }}$ January 2019), Google scholar (inception to $31^{\text {st }}$ January 2019) and Cochrane Database Reviews on 31 ${ }^{\text {st }}$ January 2019. Search strategy for PubMed included (IgA nephropathy) OR IgAN)). We searched EMBASE with key words /exp IgA GN OR IgA nephropathy AND (IgAN), Google scholar with IgA GN or IgA nephropathy and Cochrane Database Reviews with IgA nephropathy. References of included studies were hand searched for additional studies. We assessed the studies for inclusion and extracted data for review.

Primary outcome of review was prevalence of $\operatorname{IgA}$ nephropathy in India. Secondary outcomes included clinical features, laboratory findings, histopathological pattern, immunofluorescences findings and electron microscopic findings of $\mathrm{IgAN}$ from India in comparison to foreign studies.

\section{Statistical methods}

The data were entered in excel sheet and analyzed using STATA 12.0 and Cochrane Rev Man 5.1. Continuous outcome data were reported as mean and dichotomous data as percentages.

The Newcastle-Ottawa Scale (NOS) was used for assessing quality of nonrandomized studies (cohort and case-control studies). ${ }^{10}$

\section{Results}

The study selection flow diagram is shown in Figure 1. By electronic database search we found a total of 9103 records and screened titles and/or abstracts of all records. After excluding duplicates and irrelevant studies, 62 eligible studies were assessed for full texts. Full texts were found for 49 studies and these were including for qualitative synthesis and meta-analysis.

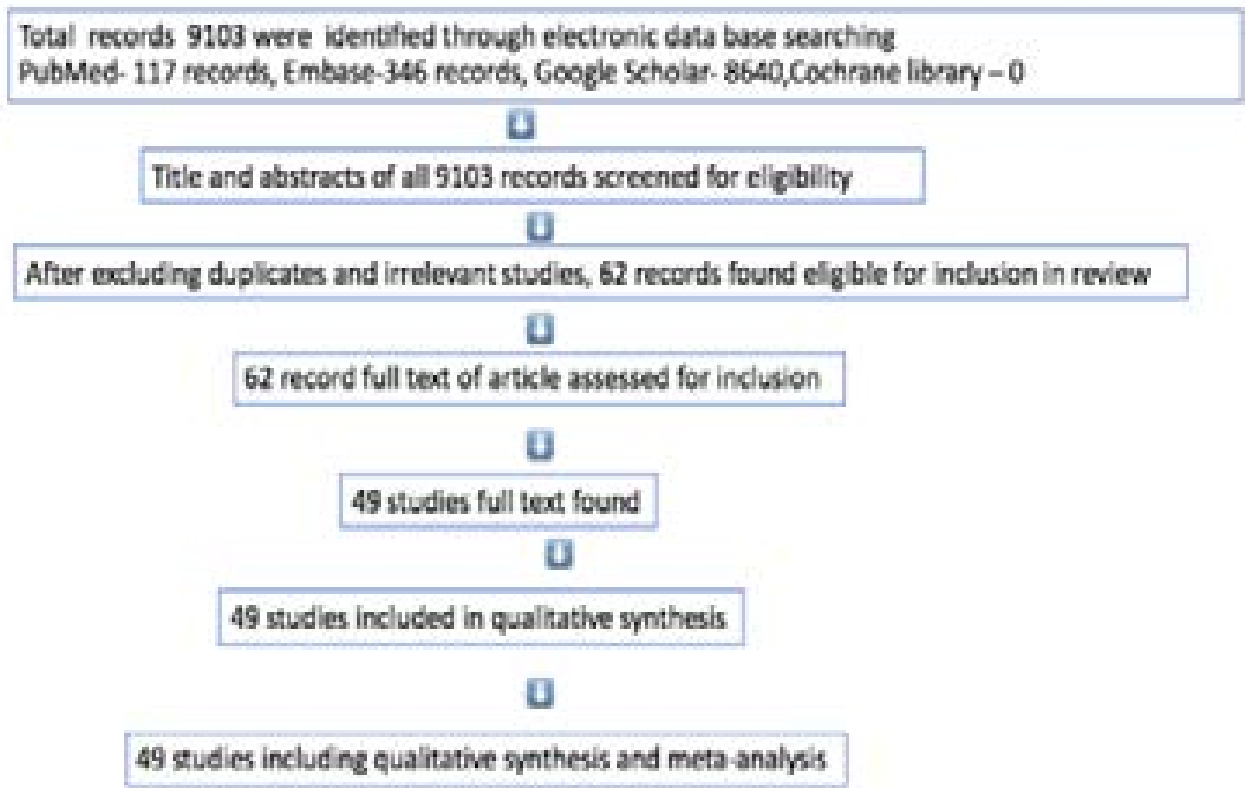

Figure 1: Study selection flow diagram

Out of 49 studies,21studies (2309 cases ) were related to Primary IgAN, ,19 studies ( 21 cases) were related to secondary IgA nephropathy ( Secondary IgAN), four studies (133 cases) were related to Henoch-Schönlein purpura (HSP) with $\operatorname{IgA}$ nephropathy or $\operatorname{IgA}$ vasculitis nephritis (IgAVN), and five studies (17cases) were related to $\operatorname{IgA}$ dominant nephropathy ( $\operatorname{Ig} A D N$ ) (figure 2). The frequency/ prevalence of IgA nephropathy was reported in 14 studies and is shown in Table1. 
Table 1: Frequencies/prevalence (\%) of IgA nephropathy in India

\begin{tabular}{|c|c|c|c|c|}
\hline $\begin{array}{l}\text { S. } \\
\text { No. }\end{array}$ & Reference & Year & $\begin{array}{l}\text { Study population } \\
\text { Children, Adult }\end{array}$ & $\begin{array}{l}\text { Prevalence of } \\
\operatorname{IgAN}(\%)\end{array}$ \\
\hline 1. & Chacko et al & 2011 & $\mathrm{C}, \mathrm{A}$ & 8.6 \\
\hline 2 & Ganesh et al & 2018 & $\mathrm{C}, \mathrm{A}$ & 21.6 \\
\hline 3 & Siddappa S & 2011 & $\mathrm{~A}$ & 7.8 \\
\hline 4 & Das et al & 2015 & $\mathrm{~A}, \mathrm{C}$ & 7.5 \\
\hline 5 & Agrawal et al & 2017 & $\mathrm{~A}$ & 2.6 \\
\hline 6 & Mittal et al & 2012 & $\mathrm{~A}$ & 8.1 \\
\hline 7 & Chandrika et al & 2009 & $\mathrm{~A}, \mathrm{C}$ & 14.2 \\
\hline 8 & Ramakrishan & 2016 & $\mathrm{~A}$ & 11.5 \\
\hline 9 & Chacko et al, & 2007 & $\mathrm{~A}, \mathrm{C}$ & 32 \\
\hline 10 & Vanikar et al, & 2005 & $\mathrm{~A}$ & 16.5 \\
\hline 11. & Bhuyan et al & 1992,87 & $\mathrm{~A}, \mathrm{C}$ & 7.24 \\
\hline 12. & Tiwari et al & 2016 & $\mathrm{~A}, \mathrm{C}$ & 14.3 \\
\hline 13 & Chowdary et al & 2018 & $\mathrm{~A}$ & 42.0 \\
\hline 14 & Dhanapriya et al & 2018 & $\mathrm{~A}$ & 5 \\
\hline \multicolumn{4}{|c|}{ After pooling the data total prevalence/frequencies } & $16.5 \%$ \\
\hline
\end{tabular}

\section{Number of Studies}
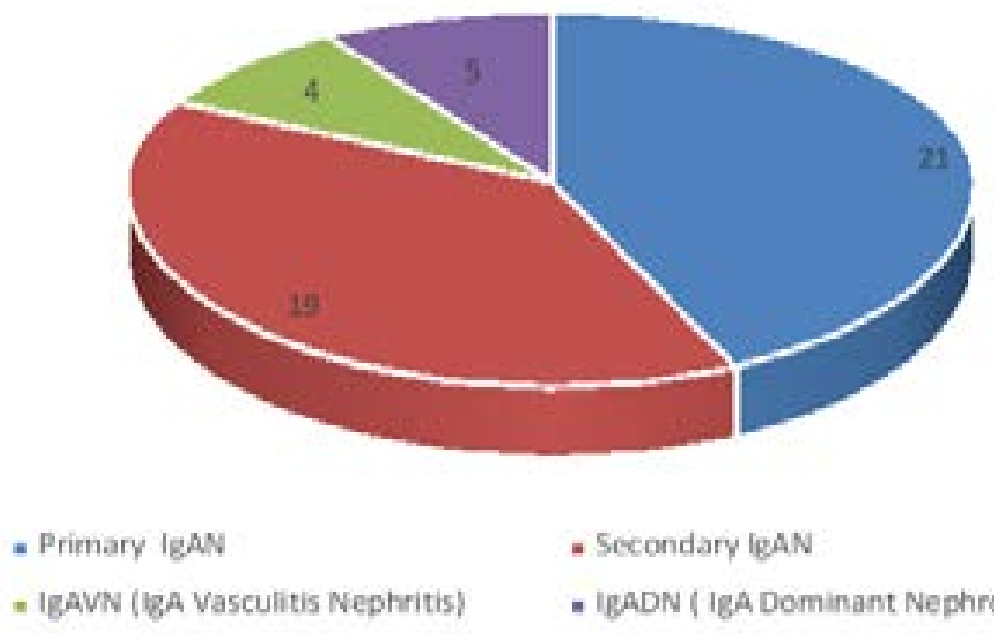

- Secondary lran

- IgADN (IgA Dominant Nephropathy)

Figure 2: Subgrouping of the 49 studies in four 
Clinical and laboratory features of Primary IgA nephropathy, IgA vasculitis nephritis (HSP), IgA dominant nephritis and Secondary IgAN are shown in Table
2. Histomorphology (MEST-C\& Haas's classification), Immunofluorescences, and Electron microscopic findings of Primary IgAN, IgAVN (HSP), IgADN and Secondary IgAN are described in Table 3.

Table 2: Clinical and Laboratory features of Primary IgA nephropathy, IgA vasculitis nephritis (HSP), IgA dominant nephritis and Secondary IgAN

\begin{tabular}{|c|c|c|c|c|c|}
\hline S.No. & Main clinical features & $\begin{array}{l}\text { Primary IgA } \\
\text { nephropathy }\end{array}$ & $\begin{array}{l}\text { IgA vasculitis } \\
\text { nephritis(HSP) }\end{array}$ & $\begin{array}{l}\text { IgA dominant } \\
\text { nephritis }\end{array}$ & $\begin{array}{l}\text { Secondary } \\
\text { IgAN }\end{array}$ \\
\hline 1. & Mean age (years) & $31.7 \pm 13.8$ & $37.5 \pm 15.8$ & $48.6 \pm 21.3$ & $27.2 \pm 16.7$ \\
\hline 2. & Male : female & $1.93: 1$ & $1.07: 1$ & $1.64: 1$ & $2: 1$ \\
\hline 3. & $\begin{array}{ll}\text { Asymptomatic } & \text { urinary } \\
\text { abnormalities }(\%) & \\
\end{array}$ & 5.5 & 1.4 & 0 & 9.5 \\
\hline 4. & Macroscopic hematuria $(\%)$ & 5.1 & 0.44 & 40.94 & 35.71 \\
\hline 5. & Microscopic hematuria( $\%)$ & 49.6 & 44.49 & 15.64 & 59.57 \\
\hline 6. & $\begin{array}{l}\text { Subnephrotic proteinuria } \\
(>1 \mathrm{~g} / \mathrm{d})(\%)\end{array}$ & 42.1 & 29.42 & 23.29 & 52.38 \\
\hline 7 & $\begin{array}{l}\text { Nephrotic range proteinuria } \\
(>3 \mathrm{~g} / \mathrm{d})(\%)\end{array}$ & 16.04 & 4.44 & 76.88 & 47.61 \\
\hline 8. & Loin or abdominal pain $(\%)$ & 1.8 & 61.72 & 0 & 4.7 \\
\hline 9. & Hypertension $(\%)$ & 25.8 & 18.39 & 35.5 & 47.61 \\
\hline 10. & $\begin{array}{l}\text { Infection-related } \\
\text { exacerbations }(\%)\end{array}$ & 10.3 & 19.14 & 47.05 & 4.7 \\
\hline 11. & Skin Rashes $(\%)$ & 0 & 99.24 & 0 & 0 \\
\hline 12. & GIT manifestation( $\%)$ & 0 & 54.83 & 5.8 & 0 \\
\hline 13. & Arthritis/arthralgia(\%) & 0 & 78.58 & 0 & 0 \\
\hline 14. & Duration of symptoms & $5.40 \pm 3.2$ & $3.91 \pm 0.59$ & $2.87 \pm 1.84$ & $2.81 \pm 3.9$ \\
\hline 15. & Raised serum creatinine & $3.04 \pm 2.6$ & $0.9 \pm 0$ & $3.21 \pm 20$ & $3.5 \pm 3.9$ \\
\hline 16. & Reduced e-GFR & $59.54 \pm 19.3$ & - & $63.6 \pm 0$ & $78 \pm 0$ \\
\hline 17. & $24 \mathrm{~h}$ urine protein $(\mathrm{g} / \mathrm{d})$ & $2.6 \pm 1.5$ & $3.2 \pm 0$ & $3.5 \pm 0.2$ & $4.7 \pm 2.3$ \\
\hline 18. & Serum C3 level reduced $(\%)$ & 0 & 0.06 & 88.47 & 0 \\
\hline
\end{tabular}


Table3: Histomorphology (MEST\& Haas's classification, Immunofluorescences and Electron microscopic findings in primary IgA nephropathy, IgA vasculitis nephritis (HSP), IgA dominant nephritis and Secondary IgAN

\begin{tabular}{|c|c|c|c|c|c|c|c|c|c|c|c|c|c|}
\hline \multirow[t]{2}{*}{ S.No. } & \multirow[t]{4}{*}{ Types IgAN } & \multicolumn{12}{|c|}{ Investigations } \\
\hline & & \multicolumn{3}{|c|}{ Histomorphology $(\%)$} & \multicolumn{5}{|c|}{ Immunofluorescence (\%) } & \multicolumn{4}{|c|}{ Electron microscopy $(\%)$} \\
\hline & & $\begin{array}{l}\text { MEST-C } \\
\text { classification }\end{array}$ & $\begin{array}{l}\text { Haas's } \\
\text { classification }\end{array}$ & \multirow[t]{2}{*}{$\begin{array}{l}\text { Skin } \\
\text { biopsy }\end{array}$} & \multirow[t]{2}{*}{ 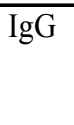 } & \multirow[t]{2}{*}{ IgA } & \multirow[t]{2}{*}{$\operatorname{IgM}$} & \multirow[t]{2}{*}{$\mathrm{C} 3$} & \multirow[t]{2}{*}{ F.H. } & \multirow[t]{2}{*}{$\mathrm{MeD}$} & \multirow[t]{2}{*}{ SubEnD } & \multirow[t]{2}{*}{ SubEpD } & \multirow[t]{2}{*}{ Both } \\
\hline & & Renal biopsy & & & & & & & & & & & \\
\hline 1. & Primay IgAN & $\begin{array}{l}\text { Me-59 } \\
\text { En-10.4 } \\
\text { SG-20.9 } \\
\text { C1-3.6 } \\
\text { C2-5.3 } \\
\text { T0-2.8 } \\
\text { T1-11.5 } \\
\text { T2- } 9.6 \\
\text { N-1.03 }\end{array}$ & $\begin{array}{l}\text { Cl I -11.1 } \\
\text { Cl II-10.6 } \\
\text { Cl III-13 } \\
\text { Cl IV-7.5 } \\
\text { Cl V-16.2 }\end{array}$ & - & 1.6 & 100 & 4.5 & 4.6 & 0.2 & 26.4 & 0.58 & 0 & 17.3 \\
\hline 2. & IgAVN & $\begin{array}{l}\text { Me-9.7 } \\
\text { En-6.7 } \\
\text { SG-0.7 } \\
\text { C1-2.2 } \\
\text { T0-2.2 }\end{array}$ & - & $\begin{array}{l}\text { LC- } \\
33.8\end{array}$ & 0 & 100 & 0 & 22.5 & 0 & - & - & - & - \\
\hline 3. & IgADN & $\begin{array}{l}\text { Me-29.4 } \\
\text { En-47.0 } \\
\text { C2-58.8 }\end{array}$ & - & - & 12.2 & 100 & 1 & 89.7 & 0 & 0 & 5.8 & 11.7 & 5.8 \\
\hline 4. & $\begin{array}{l}\text { Secondary } \\
\text { IgAN }\end{array}$ & $\begin{array}{l}\text { Me-95.2 } \\
\text { En-23.8 } \\
\text { SG-33.3 } \\
\text { C1-19 } \\
\text { T0-14.2 }\end{array}$ & - & - & 16.6 & 100 & 5.9 & 9.5 & 0 & 9.5 & 0 & 4.7 & 0 \\
\hline $\begin{array}{l}\text { Me-1 } \\
\text { Cellu } \\
>50 \% \\
\text { depo }\end{array}$ & $\begin{array}{l}\text { esangial pro } \\
\text { ar/fibrocellular }\end{array}$ & $\begin{array}{l}\text { liferation, En- } \\
\text { crescent, C2 } \\
\text { nal, Cl- Class }\end{array}$ & Endocapillary & proli & & & $\begin{array}{l}\text { G-SegI } \\
\text { ent, T } \\
\text { EnD-su }\end{array}$ & & & omeru & sclerosis & $\begin{array}{c}\text { C1- } \\
\text { 0\% TA// } \\
\text { D-subep }\end{array}$ & $\begin{array}{l}<25 \% \\
\text { helial }\end{array}$ \\
\hline
\end{tabular}

\section{Discussion}

We found combined prevalence of $\operatorname{IgAN}$ as $16.5 \%$ of in India. The prevalence of $\operatorname{IgA}$ nephropathy showed considerable variations (0.8-47\%) among geographic regions with different renal biopsy practices., ${ }^{3,625-26}$ The prevalence in India was lower than certain Asian counties e.g. Japan $(47.4 \%)$ and China(45\%). ${ }^{25-26}$ We found higher prevalence of IgAN in comparison to study by Seedate et al $(13.3 \%)$ from African country Natal done on Indians. ${ }^{27}$ The IgA nephropathy was uncommon $(0.8 \%)$ in African blacks. ${ }^{27}$ The frequencies of IgAN was higher in India than the studies from United States thathad prevalence of $10.8 \%$ and $9.4 \% .{ }^{28}$ We were unable to pool the data for incidence because the studies were not accurately defined the incidence. Primary IgAN and Secondary IgAN was found in younger age groups and it is similarly reported by other studies ${ }^{29,30}$ Males were more commonly effected than females and our findings corroborated with other studies ${ }^{27,29} \mathrm{We}$ found that $\operatorname{IgADN}$ was presented in higher age group (48.6 \pm 21.3$)$ than Primary IgAN, IgAVN, and Secondary IgAN. Similarly, Nasr et al reported IgADN in elderly age group. ${ }^{31}$ We also found rapid onset of symptoms in primary IgAN and Secondary IgAN as described by other studies., ${ }^{9,32}$ It was different from PIGN (post infection glomerulonephritis), which had a period of latency (1-2 weeks) after the symptoms of infection. ${ }^{33}$ Infection related exacerbations were associated maximum with $\operatorname{IgADN}(47 \%)$ followed by IgAVN $(19 \%)$. The similar observation was reported in a study by Satoskar et al. ${ }^{34}$ Episodic macroscopic hematria, nephrotic range proteinuria and hypertension had been typically associated with IgADN. ${ }^{35}$ We found the similar observations. Microscopic hematuria (49.6-59.5\%) and subnephrotic proteinuria (42.1-52.3\%) were more frequent in primary and secondary $\operatorname{IgAN}$ and it correlated with other studies. ${ }^{36-38}$ We found that rapidly progressive renal failure was associated with IgADN 
and secondary IgAN than primary IgAN and IgAVN and similar trend had been demonstrated by other studies. ${ }^{35,37}$ Similar to Nasr et al., we also found hypocomplementemia more in IgADN in comparison to primary and secondary IgAN and IgAVN. ${ }^{39}$ Histomorphology of primary and secondary IgAN ranged from normal to chronic glomerulonephritis and it was similar to various other studies. ${ }^{29,36,40,41}$ On IF, most biopsies showed predominantly $\operatorname{IgA}$ deposition in primary and secondary $\operatorname{IgAN}$ at mesangial region and same had been demonstrated by many studies. ${ }^{42-44}$ Electron microscopy depicted mesangial electron-dense deposition followed by both (mesangial and subendothelial) deposition in primary and secondary $\operatorname{IgAN}$, and similar findings were reported by Haas et al. ${ }^{45}$ IgAVN (HSP) showed highly variable histomorphology of glomeruli ranging from normal to diffuse proliferative and crescentic glomerulonephritis. ${ }^{46}$ Skin biopsy demonstrated leukocytoclastic vasculitis in $(33.8 \%)$ cases, which was less than other study. ${ }^{47}$

The limitation of this study was that we were unable to pool incidence of IgAN because none of studies clearly defined the data.

\section{Conclusion}

The IgA nephropathy was more prevalent in India with most common subgroup being primary IgAN. Subnephrotic proteinuria and microscopic hematuria were common clinical presentation of IgAN. Secondary IgAN and IgADN had more rapidly-progressive renal failure than primary IgAN and IgAVN.

\section{Grants and/or financial support}

Nil.

\section{Conflict of interest}

Nil.

\section{References}

1. Berger J. IgAglomerular deposits in renal disease. Transplant Proc 1969; 1:939-44

2. Berger J, Hinglais N. Les depots intercapillaires d'IgAIgG. J Urol Nephrol 1968;74: 694-695.

3. D'Amico G. The commonest glomerulonephritis in the world: IgA nephropathy. Q J Med 1987; 64:709-727 PubMed

4. Julian BA, Waldo FB, Rifai A, et al. IgA nephropathy, the most common glomerulonephritis worldwide. A neglected disease in the United States? Am J Med 1988; 84:129-132 PubMed .

5. Utsunomiya Y, Koda T, Kado T, et al. Incidence of pediatric IgA nephropathy. Pediatr Nephrol 2003; 18:511515.

6. Ueda Y, Sakai O, Yamagata M, et al. IgA glomerulonephritis in Japan. Contrib Nephrol 1975; 4:37-47.

7. Nickeleit V, Mengel M, Colvin RB. Renal Transplant Pathology.In: Jennette JC, Olson JL, Silva FG, Vivette D. D'Agati, editors. Heptinstall's Pathology of the Kidney. $7^{\text {th }}$ ed. Wolters Kluwer, 2015. p.1321-431.

8. Haas M. Histologic subclassification of IgA nephropathy: a clinicopathologic study of 244 cases. Am J Kidney Dis 1997;29:829-842 PubMed .

9. Clarkson AR, Seymour AE, Thompson AJ, et al. IgA nephropathy: a syndrome of uniform morphology, diverse clinical features and uncertain prognosis. Clin Nephrol 1977;8:459-471.

10. Wells GA, Shea B, O'Connell D, Peterson J, Welch V, Losos M, et al. The Newcastle Ottawa Scale (NOS) for assessing the quality if nonrandomized studies in meta analyses. Available from: http://www.ohri.ca/ programs/clinical_epidemiology/oxford.htm. [Last accessed on 2015 Sep 17].

11. Chacko B. $\operatorname{IgA}$ nephropathy in India: what we do know. Ren Fail. 2011;33(1):102-7. doi: 10.3109/0886022X.2010.523486.

12. Ganesh K, Nair R.R, Seethalekshmy N.V, Kurian G, Mathew A et al. A Study of Clinical Presentation and Correlative Histopathological Patterns in Renal Parenchymal Disease. IJN, 2018 Jan-Feb; 28(1): 28-34.

13. Siddappa S.; Kowsalya R.; Mythri K. IgA nephropathy in a tertiary care center from south India. Indian Journal of Nephrology (2011) 21:4 (230-234).

14. Das U, Dakshinamurty KV, Prayaga A, Uppin M. Spectrum of IgA Nephropathy in a Single Center. Saudi J Kidney Dis Transpl 2015;26(5):1057-1063.

15. Agrawal V, Singh A, Kaul A, Verma R, Jain M, Pandey R. Utility of Oxford Classification in Post-Transplant Immunoglobulin A Nephropathy. Transplantation Proceedings, 2017; 49, 2274-2279.

16. Mittal N, Joshi K, Rane S, Nada R, Sakhuja V. Primary IgA nephropathy in north India: is it different? Postgrad Med J, 2012 Jan;88(1035):15-20.

17. Chandrika B K. IgA nephropathy in Kerala, India: A retrospective study. IJPM, 2009;52(1):14-16.

18. Ramakrishnan S.; Patro K.C.; Dilip R. Outcome of renal transplantation in IgA nephropathy. Indian Journal of Transplantation (2016) 10:4 (84-85).

19. Chacko B, George JT, Neelakantan N, Korula A, Chakko JK. Outcomes of renal transplantation in patients with immunoglobulin A nephropathy in India. JPGM, 2007;(53):92-95.

20. Vanikar A.V.; Trivedi H.L.; Kanodia K.V.; Patel R.D.; Shah P.R. Pathological spectrum of primary im-

African Health Sciences, Vol 21 Issue 1, March, 2021 
munoglobulin: A nephropathy in western India. Gazzetta Medica Italiana Archivio per le Scienze Mediche, 2005; 164:(6)465-471.

21. Bhuyan U.N.; Dash S.C.; Srivastava R.N.; Tiwari S.C.; Malhotra K.K. IgA associated glomerulonephritis. Journal of the Association of Physicians of India,1992; 40: 310-313.

22. Tewari C.R, Nada R, Kaur M et al. Correlates of hematuria on glomerular histology and electron microscopy in IgA nephropathy. Med J Armed Forces India. (2016); http://dx.doi.org/10.1016/j.mjafi.

23. Chowdry AM, Najar MS, Mir MM et al. Primary IgA Nephropathy in the Kashmiri Population. Saudi J Kidney Dis Transpl 2018;29(3):680-688.

24. Dhanapriya J, Balasubramaniyan T, Maharajan SP et al. IgA-dominant Infection-related Glomerulonephritis in India: A Single-center Experience. Indian Journal of Nephrology, 2017;27:435-9 PubMed .

25. Levy M, Berger J. Worldwide perspective of IgA nephropathy. Am J Kidney Dis 1988;12:340-347 PubMed . 26. Li L-S, Liu Z-H. Epidemiologic data of renal diseases from a single unit in China: analysis based on 13,519 renal biopsies. Kidney Int 2004;66:920-923 PubMed .

27. Seedat YK, Nathoo BC, Parag KB, et al. IgA nephropathy in blacks and Indians of Natal. Nephron 1988;50:137- 141 PubMed .

28. Galla JH, Kohaut EC, Alexander R, et al. Racial difference in the prevalence of IgA-associated nephropathies [Letter]. Lancet 1984;2:522.

29. Koyama A. Nationwide and long-term survey of primary glomerulonephritis in Japan as observed in 1,850 biopsied cases. Nephron 1999;82:205-213 PubMed 30. Briganti EM, Dowling J, Finlay M, et al. The incidence of biopsy-proven glomerulonephritis in Australia. Nephrol Dial Transplant 2001;16:1364-1367 PubMed . 31. Nasr S.H. ,Vivette D., Agati . IgA-Dominant Postinfectious Glomerulonephritis: A New Twist on an Old Disease. Nephron Clin Pract 2011;119:c18-c26.

32. Galla JH. IgA nephropathy. Kidney Int 1995;47:377387 PubMed .

33. Silva FG. Acute postinfectious glomerulonephritis and glomerulonephritis complicating persistent bacterial infection. In: Jennette JC, Olson JL, Schwartz MM, et al., eds. Heptinstall's Pathology of the Kidney, $5^{\text {th }}$ ed. Philadelphia: Lippincott-Raven, 1998:389-453.

34. Satoskar AA, Nadasdy G, Plaza JA, Sedmak D,
Shidham G, Hebert L, et al. Staphylococcus infection associated glomerulonephritis mimicking IgA nephropathy. Clin J Am Soc Nephrol 2006;1:1179 86.

35. Koyama A, Kobayashi M, Yamaguchi N. Glomerulonephritis associated with MRSA infection: a possible role of bacterial superantigen. Kidney Int 1995;47:207.

36. Ibels LS, Gyory AZ. IgA nephropathy: analysis of the natural history, important factors in the progression of renal disease, and a review of the literature. Medicine 1994;73:79-102 PubMed .

37. Nakamoto Y, Iida H, Kobayashi K, et al. Hepatic glomerulonephritis: characteristics of hepatic IgA glomerulonephritis as the major part. Virchows Arch $A$ Pathol Anat Histol 1981;392:45-54.

38. Saulsbury FT. Henoch-Schonlein purpura in children: report of 100 patients and review of the literature. Medicine 1999;78:395-408 PubMed.

39. Nasr S, Fidler M, Valeri A, et al. Postinfectious glomerulonephritis in the elderly. J Am Soc Nephrol 2011;22:187-195.

40. Haas M. Histologic subclassification of $\operatorname{IgA}$ nephropathy: a clinicopathologic study of 244 cases. $A m \mathrm{~J}$ Kidney Dis 1997;29:829-842 PubMed .

41. Alamartine E, Sabatier J-C, Guerin C, et al. Prognostic factors in mesangial IgA glomerulonephritis: an extensive study with univariate and multivariate analyses. Am J Kidney Dis 1991;18:12-19 PubMed .

42. Lai KN, Lai FMM, Li PKT, et al. The clinicopathological characteristics of IgA nephropathy in Hong Kong. Pathology 1988;20:15-19 PubMed .

43. Jennette JC. The immunohistology of IgA nephropathy. Am J Kidney Dis 1988;12:348-353 PubMed.

44. Berger J, Yaneva H, Nabarra B. Glomerular changes in patients with cirrhosis of the liver. Adv Nephrol Necker Hosp 1978;7:3-14 PubMed.

45. Haas M. A reevaluation of routine electron microscopy in the examination of native renal biopsies. $J \mathrm{Am}$ Soc Nephrol 1997;8:70-76.

46. Haas M, Reich HN. Morphologic markers of progressive immunoglobulin A nephropathy. Adv Chronic Kidney Dis 2012;19:107-113.

47. Poterucha TJ, Wetter DA, Gibson LE, et al. Histopathology and correlates of systemic disease in adult Henoch-Schönlein purpura: a retrospective study of microscopic and clinical findings in 68 patients at Mayo Clinic. J Am Acad Dermatol. 2013;68:420-424 PubMed . 